\title{
Physical exercise as a non-pharmacological strategy for reducing behavioral and psychological symptoms in elderly with mild cognitive impairment and dementia: a systematic review of randomized clinical trials
}

\author{
Exercício físico como estratégia não farmacológica para a redução de sintomas \\ psicológicos e comportamentais em idosos com comprometimento cognitivo leve e \\ demência: revisão sistemática de ensaios clínicos randomizados
}

Susana Ligia da Silva RODRIGUES', Jamily Matias da SILVA', Maria Clara Cordeiro de OLIVEIRA², Charleny Mary Ferreira de SANTANA', Kaliandra Meneses CARVALHO',

Breno José Alencar Pires BARBOSA ${ }^{1,3,4}$

\begin{abstract}
Background: Elderly people with dementia may exhibit behavioral and psychological symptoms throughout the course of disease. Nonpharmacological therapies, such as regular physical activity, are considered strategies for managing these symptoms. Objective: The aim of this study was to investigate whether participation in physical exercise programs is effective in reducing behavioral and neuropsychiatric symptoms in elderly people with Mild Cognitive Impairment $(\mathrm{MCI})$ and dementia. Methods: A literature review was carried out in MEDLINE (PubMed), SciELO, Web of Science, Scopus and SPORTDiscus databases from 2010 to 2020. The eligible studies were randomized clinical trials involving elderly people with mild cognitive impairment or dementia and assessing changes in neuropsychiatric and psychological symptoms as primary or secondary outcomes. The studies had a group with only physical exercise as an intervention compared to a control group. Results: Of 175 publications identified in the initial survey, only 7 studies met the eligibility criteria. Four out of 7 studies demonstrated positive effects in reducing behavioral symptoms, while the others did not report differences between gains according to the type of protocol. Conclusions: Moderate to intense aerobic and muscle strengthening exercises may have a potential benefit in the management of behavioral and psychological symptoms in dementia, but studies varied in their conclusions. This review indicates the need for further intervention studies to investigate, as a primary outcome, the absolute effect of physical exercise and its impact on behavioral and psychological symptoms in elderly people with $\mathrm{MCl}$ dementia, especially in the early stages of the disease.
\end{abstract}

Keywords: Behavior; Dementia; Exercise; Medication Adherence.

RESUMO

Antecedentes: Idosos com demência podem manifestar sintomas comportamentais e psicológicos durante o percurso da doença. Terapias não farmacológicas, como por exemplo a atividade física regular, são consideradas como uma das estratégias para manejar esses sintomas. Objetivo: O objetivo deste estudo é investigar se a participação em programas de exercício físico é efetiva na redução de sintomas comportamentais e neuropsiquiátricos de idosos com comprometimento cognitivo leve (CCL) e demência. Métodos: Foi realizada uma revisão da literatura nas bases de dados Medical Literature Analysis and Retrieval System Online - MEDLINE (PubMed), Scientific Electronic Library Online (SciELO), Web of Science, Scopus e SPORTDiscus de 2010 a 2020. Os estudos elegíveis foram: ensaios clínicos randomizados envolvendo idosos com CCL ou demência, que medissem como desfecho primário ou secundário a mudança nos sintomas neuropsiquiátricos e psicológicos. Os estudos tiveram grupo com apenas o exercício físico como intervenção em comparação a um grupo

\footnotetext{
${ }^{1}$ Instituto de Medicina Integral Prof. Fernando Figueira, Recife PE, Brazil.

${ }^{2}$ Centro Universitário Maurício de Nassau, Recife PE, Brazil.

${ }^{3}$ Universidade Federal de Pernambuco, Centro de Ciências Médicas, Área Acadêmica de Neuropsiquiatria, Recife PE, Brazil.

4 Universidade de São Paulo, Faculdade de Medicina, Departamento de Neurologia, Grupo de Neurologia Cognitiva e do Comportamento, São Paulo SP, Brazil. SLSR (D) https://orcid.org/0000-0002-8130-5679; JMS (ID) https://orcid.org/0000-0003-1100-0324; MCCO (D) https://orcid.org/0000-0002-8162-0863; CMFS (D) https://orcid.org/0000-0002-3066-8939; KMC (D) https://orcid.org/0000-0003-3439-9876; BJAPB (D) https://orcid.org/0000-0003-4333-2024 Correspondence: Breno José Alencar Pires Barbosa; Email brenojb@gmail.com.
}

Conflict of interest: There is no conflict of interest to declare.

Authors' contributions: SLSR: data interpretation and manuscript revision; JMS, MCCO: data curation and manuscript writing; CMFS, KMC, BJAPB: study supervision and manuscript revision.

Received on November 25, 2020; Received in its final form on March 11, 2021; Accepted on March 30, 2021. 
controle. Resultados: De 175 publicações identificadas na pesquisa inicial, apenas sete estudos atenderam aos critérios de elegibilidade. Quatro em sete estudos demonstraram efeitos positivos na redução dos sintomas comportamentais, enquanto os demais não fizeram diferenciação entre os ganhos conforme o tipo de protocolo. Conclusões: Exercícios aeróbicos e de fortalecimento muscular de intensidade moderada a vigorosa podem ter um benefício potencial no manejo dos sintomas psicológicos e comportamentais da demência. Esta revisão mostrou a necessidade de mais estudos de intervenção, buscando investigar como desfecho primário o efeito absoluto do exercício físico e seu impacto nos sintomas comportamentais e psicológicos de idosos com CCL e demência, principalmente nas fases iniciais da doença.

Palavras-chave: Comportamento; Demência; Exercício Físico; Adesão à Medicação.

\section{INTRODUCTION}

Dementia is a group of conditions characterized by cognitive and behavioral decline with functional impact, commonly related to neurodegenerative processes ${ }^{1}$. Mild cognitive impairment (MCI) can represent the prodromal phase of dementia, in which patients usually have cognitive complaints with relatively preserved functions daily living².

Ageing, female gender, degree and type of dementia, as well as the APOE (apolipoprotein E) epslion-4 allele influence the occurrence of neuropsychiatric symptoms (NPS) in dementia ${ }^{3}$. Behavioral and psychological symptoms in dementia (BPSD) are described as a heterogeneous group of symptoms including disturbances in thinking content, mood and behavior that frequently manifest in people with dementia ${ }^{4}$.

At least one type of behavioral and/or psychological symptom is expected at any stage of dementia, especially in mild to moderate stages. ${ }^{5}$ The manifestation of BPSD can be observed as behavioral changes such as physical or verbal aggression, agitation, wandering, and sexual disinhibition that are usually accompanied by anxiety, depression, apathy and psychosis (hallucinations and delusions) ${ }^{6}$.

The presence of BPSD negatively affects patients' quality of life, resulting in deterioration of cognitive abilities, caregiver burden, early institutionalization, and increased treatment costs 5 . For example, in the United States, about US\$ 228 billion was estimated for the care of patients with dementia in $2018^{7}$, while in Brazil, in a tertiary center, the cost was estimated at approximately US $\$ 1,683.18$ per patient $/$ month $^{8}$.

The practice of physical activity has shown promising results in improving agitation in patients with dementia9. Non-pharmacological approaches, such as frequent practice of exercise are known to be the most effective alternative in the treatment of these symptoms ${ }^{10}$. Exercise is considered a subcategory of physical activity being performed in a planned, structured, repetitive and intentional way, to improve or maintain one or more components of physical activity and health in general ${ }^{11}$. Studies indicate that aerobic exercises, if practiced over a certain period of time, are capable of containing symptoms of depression and anxiety in elderly people with dementia ${ }^{12}$. Aerobic exercise (15 min) combined with resistance training three times a week for 3 weeks reduced agitation in elderly with severe cognitive impairment in one study ${ }^{13}$. Other study reported that sedentary elderly had more neuropsychiatric symptoms ${ }^{14}$. In patients with MCI, exercise training (6 months) is likely to improve cognitive ability ${ }^{2}$.

Previous studies addressing this theme have presented results of physical activity combined with various interventions ${ }^{9,15,16}$. On the other hand, studies that evaluate the effects of exercise alone on behavioral symptoms are scarce and existing studies lack methodological quality ${ }^{15}$. Little is known about which type of exercise is more appropriate, as well as the exercise parameters, such as intensity and frequency, that are able to promote significant results in such population.

Our hypothesis is that the practice of regular physical exercises under supervision and with appropriate protocols could reduce BPSD in elderly with MCI and dementia. This paper aimed to investigate whether the participation of elderly people in physical exercise programs is effective in reducing behavioral and psychological symptoms of dementia, in order to contribute to the decision-making process of healthcare professionals based on scientific evidence, and helping them to better manage these symptoms.

\section{METHODS}

A systematic review of the literature was carried out to answer the initial question: does physical exercise reduce behavioral and psychological symptoms in elderly people with mild cognitive impairment and dementia? This review was conducted in accordance with the recommendations of the "Preferred Reporting Items of Systematic Reviews" (PRISMA) ${ }^{17}$.

\section{Eligibility criteria}

The PICOS strategy (Population, Intervention, Control, Outcomes, Settings) was used in order to establish the inclusion and exclusion criteria. The eligible studies were randomized clinical trials involving elderly people with mild cognitive impairment (MCI) or dementia (any disease stage), which measured neuropsychiatric and psychological symptoms as a primary or secondary outcome and comprised physical exercise as an intervention compared to a control group. Studies in animals, studies involving only caregivers and those that did not evaluate behavioral and psychological symptoms were excluded. 


\section{Search strategy}

Two independent researchers conducted an electronic search in MEDLINE (PubMed), SciELO, Web of Science, Scopus and SPORTDiscus databases in July 2020. The filters applied included clinical trials published in the last 10 years, without language restriction. The search strategy combined the following standardized descriptors according to MeSh/ Decs: (((dementia OR "Mild Cognitive Impairment") AND (exercise) AND ("behavioral symptoms" OR "neuropsychiatric symptoms")).

\section{Eligibility screening}

The first stage of article selection was based the title and summary of articles. The articles were screened and selected according to their relevance and inclusion criteria, and were analyzed by two independent researchers. If different opinions emerged, a third researcher would be consulted in order to make the final decision.

\section{Data extraction}

Data were extracted and entered in a spreadsheet to allocate the following variables: author, year of publication, place where the study was developed, sample size and characteristics, main outcomes analyzed, type of intervention and main conclusions, as demonstrated in Tables 1 and 2.
The Physiotherapy Evidence Database (PEDro) ${ }^{18}$ criteria were used to evaluate the methodological quality of the studies.

\section{RESULTS}

The literature search resulted in 129 articles after duplicates were removed. All were examined for title and abstract, and 109 of them were excluded because they were not related to the theme or had a study design not contemplated in the present study. The remaining 20 articles were fully read and, at this stage, 13 articles were excluded. The remaining seven articles met the inclusion criteria and were used for analysis. Figure 1 summarizes the literature search process.

Tables 1 and 2 summarizes the main information of the studies included in this review. The included articles were published between 2015 and 2020, all in English language, and the mean age of participants varied from 70.5 to 86.7 years old.

All studies used cognitive measurement scales (e.g. Mini Mental State Examination - MMSE, Cognitive Subscale of Alzheimer's Disease Assessment Scale - ADA-Cog), functionality (e.g. Sit-to-stand test, 6-minute walk test, Timed up and go - TUG, Katz index), quality of life (e.g. Quality of life

Table 1. Characteristics of studies that examined the effects of physical exercise on behavioral/neuropsychiatric symptoms in elderly people with dementia.

\begin{tabular}{|c|c|c|c|c|}
\hline $\begin{array}{l}\text { Author } \\
\text { (year) }\end{array}$ & Country & Sample, mean age & Characterization & Instruments \\
\hline $\begin{array}{l}\text { Ballard } \\
\text { et al. } \\
(2016)^{20}\end{array}$ & $\begin{array}{l}\text { United } \\
\text { Kingdom }\end{array}$ & $\begin{array}{c}\mathrm{n}=277 \text { (G1: antipsychotic review=146; G2: no antipsychotic } \\
\text { review=131), institutionalized } \\
43 \text { males/120 females } \\
85.2 \text { years old (IG: } 86,9 ; \text { CG: } 86,4)\end{array}$ & $\begin{array}{l}\text { Mild to advanced } \\
\text { stages of dementia } \\
\text { Sedentary }\end{array}$ & $\begin{array}{l}\text { NPI, CSDD, } \\
\text { CMAI }\end{array}$ \\
\hline $\begin{array}{l}\text { Hoffmann } \\
\text { et al. } \\
(2016)^{23}\end{array}$ & Denmark & $\begin{array}{c}\mathrm{n}=200(\mathrm{IG}=107, \mathrm{CG}=93) \text {, outpatient memory clinic } \\
113 \text { males/87 females } \\
\text { 70.5 years old (IG: 69.8; CG: } 71.3)\end{array}$ & $\begin{array}{c}\text { Mild AD } \\
\text { Physically active }\end{array}$ & NPI, HAM-D \\
\hline $\begin{array}{l}\text { Cancela } \\
\text { et al. } \\
(2016)^{22}\end{array}$ & Spain & $\begin{array}{c}n=189(\mid \mathrm{G}=73, C G=116), \text { institutionalized } \\
63 \text { males/126 females } \\
81.7 \text { years old }(I G: 80.6 ; C G: 82.9)\end{array}$ & $\begin{array}{l}\text { Unespecified stage } \\
\text { of dementia } \\
\text { Sedentary }\end{array}$ & NPI, CSDD \\
\hline $\begin{array}{l}\text { Telenius } \\
\text { et al. } \\
(2015)^{24}\end{array}$ & Norway & $\begin{array}{c}n=163(\mid \mathrm{G}=82, C G=81), \text { institutionalized } \\
43 \text { males/120 females } \\
\text { 86,7 years old }(I G: 86.9 ; G C: 86.4)\end{array}$ & $\begin{array}{c}\text { Mild to moderate AD } \\
\text { Sedentary }\end{array}$ & NPI, CSDD \\
\hline $\begin{array}{l}\text { Öhman } \\
\text { et al. } \\
(2017)^{21}\end{array}$ & Finland & $\begin{array}{c}\mathrm{n}=179 \text { (home- } \text { based exercises }=63 \text {, group exercises }=57, \mathrm{CG}=59) \\
\text { voluntary } \\
110 \text { males/69 females } \\
77.8 \text { years old (G1:77.4; G2: 77.9;CG: 78.1) }\end{array}$ & $\begin{array}{c}\text { Mild to advanced AD } \\
\text { NA }\end{array}$ & NPI, CSDD \\
\hline $\begin{array}{l}\text { Lamb } \\
\text { et al. } \\
(2018)^{25}\end{array}$ & England & $\begin{array}{c}\mathrm{n}=494(\mathrm{IG}=329, \mathrm{GC}=165), \text { memory clinics, general hospitals, } \\
\text { community dementia services, primary care } \\
301 \text { males/69 females } \\
77 \text { years old (IG: } 76.9 ; \mathrm{GC}: 78.4)\end{array}$ & $\begin{array}{l}\text { Mild to moderate } \\
\text { dementia } \\
\text { NA }\end{array}$ & NPI \\
\hline $\begin{array}{l}\text { Henskens } \\
\text { et al. } \\
(2018)^{19}\end{array}$ & Netherlands & 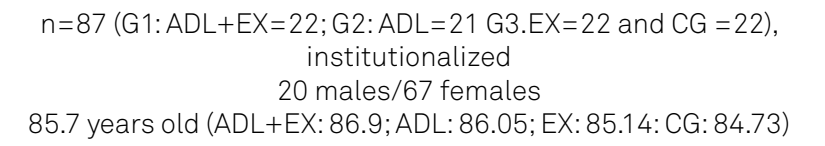 & $\begin{array}{l}\mathrm{MCl} \text { to advanced } \\
\text { dementia } \\
\text { NA }\end{array}$ & $\begin{array}{l}\text { CMAI, CSDD, } \\
\text { AES }\end{array}$ \\
\hline
\end{tabular}

AD: Alzheimer's disease; NPI: Neuropsychiatric Inventory; CSDD: Cornell Scale for Depression in Dementia; HAM-D: Hamilton's Depression Rating Scale; ADCSCGIC: Alzheimer's Disease Cooperative Study - Clinicians Global Impression of Change; CMAl: Cohen-Mansfield Agitation Inventory; CG: control group; IG: intervention group; ADL: daily living activity; EX: exercise; AES: Apathy Assessment Scale. 
Table 2. Intervention and outcomes of studies that examined the effects of physical exercise on behavioral/neuropsychiatric symptoms in elderly people with dementia.

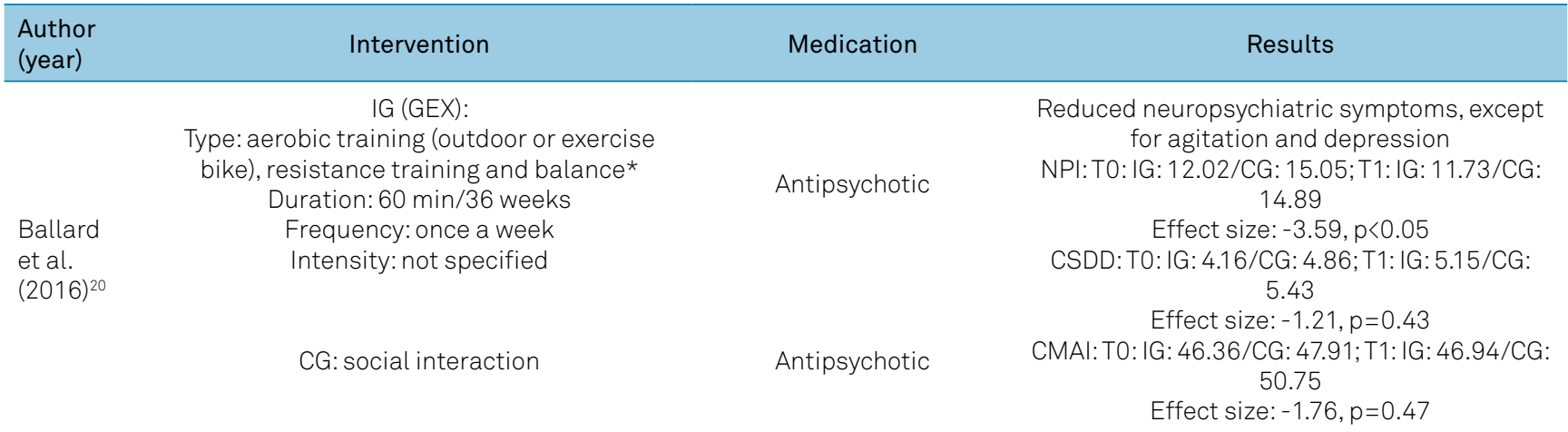

\begin{tabular}{|c|c|c|c|}
\hline $\begin{array}{l}\text { Hoffmann } \\
\text { et al. } \\
(2016)^{23}\end{array}$ & $\begin{array}{c}\text { IG: } \\
\text { Type: aerobic exercise: } 3 \times 10 \text { min. on } \\
\text { ergometer bicycle, cross trainer and treadmill } \\
(2-5 \text { min rest between }) \\
\text { Duration: } 60 \text { min } / 16 \text { weeks } \\
\text { Frequency: three weekly sessions } \\
\text { Intensity: moderate to vigorous } \\
\text { CG: usual care }\end{array}$ & $\begin{array}{c}\text { Anti-dementia } \\
\text { (acetylcholinesterase } \\
\text { inhibitors and/or } \\
\text { memantine) } \\
\text { Antidepressant } \\
\\
\text { Anti-dementia } \\
\text { (acetylcholinesterase } \\
\text { inhibitors and/or } \\
\text { memantine) } \\
\text { Antidepressant }\end{array}$ & $\begin{array}{r}\text { Reduced neuropsychiatric symptoms, except } \\
\text { for depression } \\
\text { NPI:T0: IG: } 10.0 / C G: 9.4 ; T 1: \text { IG: } 8.8 / C G: 11.4 \\
\text { Effect size: }-3 ., 5, p=0.002 \\
\text { HAM-D: TO: IG: } 1.9 / C G: 2.0 ; T 1: / / G: 1.7 / C G: 1.8 \\
\text { Effect size: }-0.1, p=0.791\end{array}$ \\
\hline
\end{tabular}

IG:

Type: aerobic training (recumbent bicycle) Duration: $15 \mathrm{~min} / 60$ weeks

Frequency: daily **

Cancela

et al. Intensity: self-selected

$(2016)^{22}$

CG: recreational activities (card games, reading and manual work)
Anti-dementia (acetylcholinesterase inhibitors and/or memantine)

Anti-dementia (acetylcholinesterase inhibitors and/or memantine)

\begin{tabular}{|c|c|c|c|}
\hline $\begin{array}{l}\text { Telenius } \\
\text { et al. } \\
(2015)^{24}\end{array}$ & $\begin{array}{c}\text { IG: } \\
\text { Type: resistance training for lower limb } \\
\text { muscles (12 MR) and } 2 \text { balance exercises } \\
\text { Duration: } 50 \text { to } 60 \text { min/12 weeks } \\
\text { Frequency: twice weekly sessions } \\
\text { Intensity: vigorous } \\
\text { CG: mild physical activity, reading, games, } \\
\text { talking, listening to music }\end{array}$ & NA & $\begin{array}{l}\text { Reduced apathy and agitation, except for } \\
\text { depression } \\
\text { NPI:T0: IG: } 5.8 / C G: 4.8 ; \text { T1: IG: } 5.1 / C G: 5.4 \\
\text { Effect size: Apathy: } 0.3, p=0.048 \\
\text { Agitation: } 0.2, p=0.07 \\
\text { CSDD: T0: IG: } 4.7 / C G: 4.9 ; \text { T1: IG: 3.8/CG: } 3.8 \\
\text { Effect size: } 0.2, p=0.39\end{array}$ \\
\hline $\begin{array}{l}\text { Öhman } \\
\text { et al. } \\
(2017)^{21}\end{array}$ & $\begin{array}{l}\text { IG (GE and HE): } \\
\text { Type: aerobic training (Nordic walking and } \\
\text { bike); resistance training; balance and dual- } \\
\text { task exercises (15 min for each modality) } \\
\text { Duration: } 60 \text { min/52 weeks } \\
\text { Frequency: twice weekly sessions } \\
\text { Intensity: gradually increased } \\
\text { CG: usual care (physical therapy, if necessary) }\end{array}$ & $\begin{array}{l}1 \text { in 4: Antidepressant } \\
1 \text { in 10: Antipsychotic }\end{array}$ & $\begin{array}{c}\text { No improvements in neuropsychiatric } \\
\text { symptoms } \\
\text { NPI:TO: IG: (GE:12.05, HE: 13.45)/CG: 16.56; } \\
\text { T1: NA } \\
\text { Effect size: not significant/NA, p=0.41 } \\
\text { CSDD: T0: IG: (GE:3.9, HE: 4.8)/CG: } 5.9 ; \text { T1: NA } \\
\text { Effect size: not significant/NA, } p=0.81\end{array}$ \\
\hline $\begin{array}{l}\text { Lamb } \\
\text { et al. } \\
(2018)^{25}\end{array}$ & $\begin{array}{c}\text { IG: } \\
\text { Type: aerobic training (static cycling) and } \\
\text { resistance training (5 exercises for arms and } \\
\text { legs) } \\
\text { Duration: } 60-90 \text {-min/16 weeks } \\
\text { Frequency: twice weekly sessions } \\
\text { Intensity: moderate to vigorous*** }\end{array}$ & $\begin{array}{c}\text { Anti-dementia } \\
\text { (acetylcholinesterase } \\
\text { inhibitors and/or } \\
\text { memantine) } \\
\\
\text { Anti-dementia } \\
\text { (acetylcholinesterase } \\
\text { inhibitors and/or } \\
\text { memantine) }\end{array}$ & $\begin{array}{l}\text { No improvements in neuropsychiatric } \\
\text { symptoms } \\
\text { NPI:T0: IG: } 7.5 / C G: 10 ; T 1: \text { IG: } 12 / C G: 9 \\
\text { Effect size: }-2.1, p=0.14\end{array}$ \\
\hline
\end{tabular}




\begin{tabular}{|c|c|c|c|}
\hline $\begin{array}{l}\text { Author } \\
\text { (year) }\end{array}$ & Intervention & Medication & Results \\
\hline \multirow[t]{2}{*}{$\begin{array}{l}\text { Henskens } \\
\text { et al. } \\
(2018)^{19}\end{array}$} & $\begin{array}{c}\text { IG (GEX): } \\
\text { Type: aerobic training (walk outdoors - } \\
500 \text { mts or } 1 \mathrm{~km} \text { ), resistance training: } 13 \\
\text { exercises for upper and lower extremities and } \\
\text { the torso: } 3 \text { sets of } 8 \text { reps } \\
\text { Duration: } 30-45-\text { min/24 weeks } \\
\text { Frequency: three weekly sessions } \\
\text { Intensity: gradually increased }\end{array}$ & NA & \multirow[t]{2}{*}{ 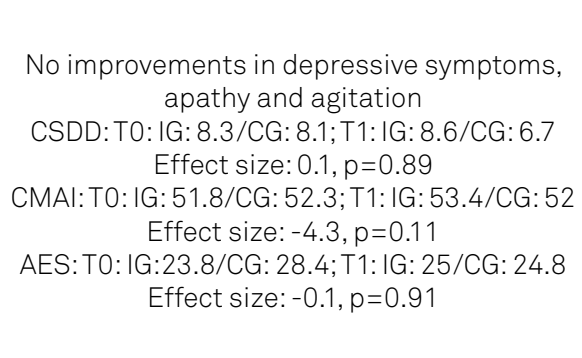 } \\
\hline & $\begin{array}{c}\text { CG: social interaction (drinking tea)/usual } \\
\text { care }\end{array}$ & NA & \\
\hline
\end{tabular}

AD: Alzheimer's disease; NPI: Neuropsychiatric Inventory; UULL: upper limbs; LLLL: lower limbs; CSDD: Cornell Scale for Depression in Dementia; HAM-D: Hamilton's Depression Rating Scale; ADCS-CGIC: Alzheimer's Disease Cooperative Study - Clinicians' Global Impression of Change; CMAI: Cohen-Mansfield Agitation Inventory; CG: Control group; IG: Intervention Group; ADL: daily living activity; GEX: exercise group; HE: tailored home-based exercise; GE: group-based exercise; AES: Apathy Assessment Scale; MTS: meters; KM: kilometer; REPS: repetitions; MR: maximum repetitions; T0: Baseline score (mean); T1: Score after intervention (mean); NA: not available; *Walking was encouraged as a routine activity, as were dancing, musical exercises, and chair volleyball; **|t was not specified whether the bicycle exercise was performed 5 or 7 times a week; $* \star \star$ Participants were asked to exercise at home for an additional hour each week.

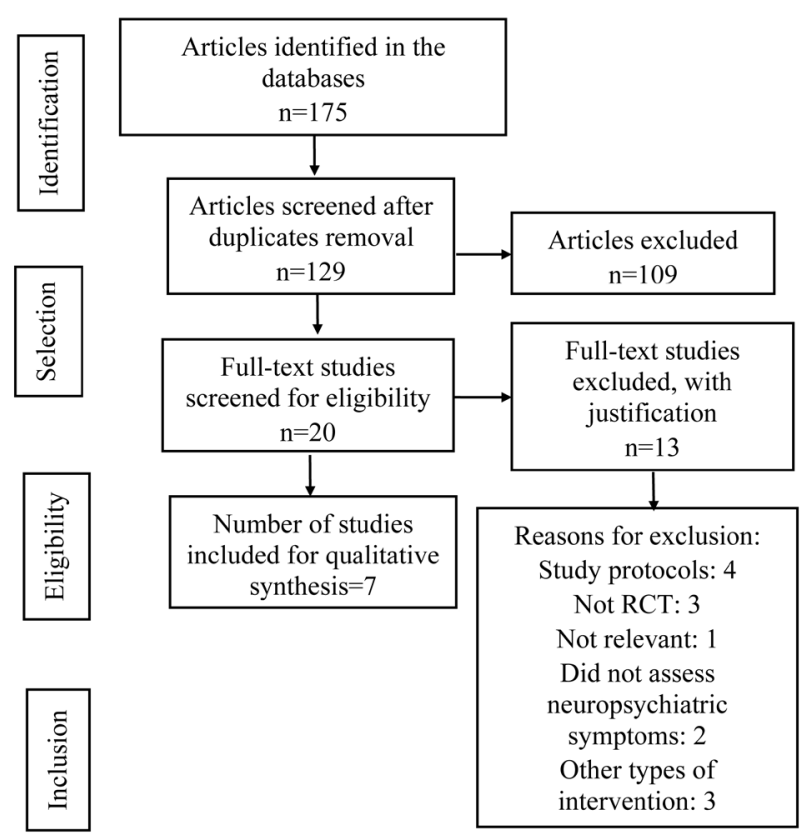

Figure 1. Flowchart of studies included for qualitative synthesis.

in Alzheimer's disease scale - QoL-AD, European quality of life - 5 dimensions - EQ-5D), neuropsychiatric symptoms (Neuropsychiatric Inventory - NPI), as well as depression, apathy and agitation (Hamilton Depression Rating Scale - HAM-D, Cohen-Mansfield Agitation Inventory - CMAI, Cornell Scale for Depression in Dementia - CSDD, Apathy Evaluation Scale - AES).

Overall, studies focused on early to moderate stages of dementia. In three studies, $\mathrm{MCI}^{16}$ and advanced phase were also included ${ }^{19,20,21}$, while one study did not specify the disease stage ${ }^{22}$. Dementia stage was classified by the CDR (clinical dementia rating) in 4 of the 7 studies. Female participants represented the majority of subjects in most studies.
Moreover, the degree of sedentarism was specified in only 3 of the 7 studies included for analysis.

Physical exercise interventions consisted mainly of strength, resistance and balance trainings, as well as aerobic exercises. Resistance exercises focused on improving muscle bulk of upper limbs, lower limbs, and trunk (squats, knee extension, pull, elevation and pulley exercises etc.). Balance training often included simple steps involved in dancing or tandem walking. Double-task exercises consisted of speaking while walking, singing during training, and performing manual tasks simultaneously while counting up, and aerobic exercises were performed in the bicycle or treadmill devices.

The period of the intervention ranged from 2 to 60 weeks, 2 to 5 times a week, with sessions duration ranging from 15 to 90 minutes. Exercise intensity ranged from moderate to vigorous, with the exception of the study by Cancela et al. ${ }^{22}$ in which participants could modulate the intensity themselves. For control groups, the activities included usual care, manual work, music therapy, reading, and social interaction. The seven studies that met the eligibility criteria are summarized below.

Ballard et al. ${ }^{20}$ carried out a cluster randomized clinical trial and evaluated the impact of an antipsychotic review, social interaction, and exercise associated with person-centered care on NPS of 277 individuals with mild to advanced dementia who lived in nursing homes in the UK. The effect of an exercise training program (stretching, muscle strengthening, aerobic and balance exercises), once a week for 36 weeks was sufficient to significantly reduce general NPS according to the measured scales (NPI), except for agitation and depressive symptoms.

Hoffmann et al. ${ }^{23}$ examined 200 individuals with a clinical diagnosis of mild Alzheimer's Disease (AD), according to the NINDS-ADRDA Alzheimer's criteria, recruited from an outpatient memory clinic in Denmark. Participants 
were randomized into two treatment groups (IG: aerobic and strengthening exercises; CG: usual care). The exercise program was conducted in a group of 3 to 5 participants. Throughout the first four weeks, the aim was to adapt participants to the training and improve the strength of their lower limbs (twice a week); in the remaining twelve weeks, the patients underwent aerobic training (stationary bike, cross-training, and treadmill) three times a week in a moderate to vigorous intensity. The results pointed to the benefits of exercise training for controlling NPS, with significant reduction of symptoms according to the measured scales (NPI). Nevertheless, no effects on depressive symptoms were reported.

Cancela et al. ${ }^{22}$ developed a randomized clinical trial with 188 institutionalized patients with dementia, according to the Diagnostic and Statistical Manual of Mental Disorders, unspecified stage. The experimental group undertook daily bicycle exercise for 15 minutes, alone or in pairs, for 60 weeks with self-selected intensity, while the control group performed sedentary recreational activities. Significant improvements were observed in the reduction of neuropsychiatric disorders according to the measured scales (NPI), with no improvement in depression.

According to the study by Telenius et al. ${ }^{24}$ vigorous-intensity lower limb strengthening and balance exercises (12 repetitions maximum), twice a week, with a 50 to 60 minutes of duration was sufficient to significantly reduce apathy and agitation in institutionalized men and women with mild to moderate dementia, with an mean age of $86.9 \pm 7$ years old. The NPI was used to assess the severity of common behavioral and neuropsychiatric symptoms in dementia. Each symptom is assessed as present or absent; if present, the severity is classified as mild, moderate or severe. NPI subscales were also used. The subscales consisted of: 1) agitation: items of agitation/aggression, irritability and disinhibition (minimum score: 0, maximum: 9); 2) affective: items of depression and anxiety (minimum score: 0 , maximum: 6); 3) apathy: symptom analyzed solely.

Ohman et al. ${ }^{21}$ randomized elderly people with mild to advanced $\mathrm{AD}$ (mean age 77.8 years old) into three groups that performed different types of treatment (G1: home-based exercises; G2: exercises in daycare centers; CG: usual care). For both exercise groups, the sessions consisted of $60 \mathrm{~min}-$ utes comprising multicomponent training sessions (aerobic exercise, strength, balance, and dual-task exercises) twice a week with progressively increasing intensity. After 48 weeks, a small decrease in irritability levels in the daycare exercise group was observed, with a -0.49 score (95\%CI 0.99-0.54, $\mathrm{p}=0.03$ ). When examining the effects in NPS subgroups, the effect sizes remained below statistical significance. To assess the NPS, the NPI was used, an instrument that assesses symptoms commonly observed in dementia: agitation, dysphoria, delusions, aberrant motor behavior, euphoria, disinhibition, anxiety, apathy, irritability, hallucinations, sleep disturbances, besides appetite and eating abnormalities. Regarding depressive symptoms, CSDD was used to assess depression and its changes over 12 months, which were modest: in G1: 1.35 (95\%CI 0.14-2.66), in G2: 0.5 (95\%C: $0.67-$ 1.54), and in G3: 0.04 (95\%CI 1.56-1.40). The scale contains 19 items with a maximum score of 38 and a score $>10$ indicates depression.

Lamb et al..$^{25}$ randomized 494 individuals with mild to moderate dementia recruited from memory clinics, general hospitals, community dementia services, and primary care in England. Behavioral symptoms were measured by NPI after 12 weeks of aerobic training (stationary bike) and resistance training (upper and lower limbs), performed in a moderate to high intensity twice a week. This intervention, however, did not promote a reduction in NPS.

Henskens et al. ${ }^{19}$ randomized 87 elderly people with MCI to advanced dementia who lived in psychogeriatric wards in the Netherlands into three intervention groups (G1: activities of daily-living (ADL); G2: exercise; G3: ADL+exercise). Participants in the control group drank tea three times per week with the nursing team to control the social aspect. Depressive symptoms were measured by the CSDD and the Apathy Evaluation Scale-10 was used to measure patients' apathetic behavior (scores from 0 to 40 ; higher scores indicate more apathetic behavior). The CMAI was used to measure the frequency of agitated behavior. The exercise program consisted of aerobic (outdoor walking) and strength training (upper and lower limbs and trunk) sessions, performed in groups (4-6 participants), three times a week, and the intensity was progressively increased in both groups. The reports obtained on exercise intensity suggested that there were some deviations in the intended exercise protocol: for example, two sets of repetitions were performed instead of the intended three sets and, regarding aerobic exercise, the participants did not always reach a distance of $500 \mathrm{~m}$ or $1 \mathrm{~km}$ due to time restrictions. After 24 weeks, no significant effect of exercise was found on depressive symptoms, apathy, and agitation when compared to the sedentary group.

All randomized clinical trials demonstrated good methodological quality (over 6 points) according to the criteria of internal validity and statistical description of the PEDro Scale (Table 3). On this scale, each article receives a score ranging from 0 to 10 . All trials used randomization methods with secret allocation; besides, participants had similar baseline characteristics, comparisons were carried out between groups, and they have included means and variability of results. Due to the nature of the research, none of the studies could blind the participants or therapists. Most evaluators were blinded with regards to the analysis of the results (5 studies), measuring key outcomes in more than $85 \%$ of the participants (4 studies), and analyzed the data according to the intention to treat principles (5 studies). 
Table 3. PEDro scale items and scores of the included studies.

\begin{tabular}{|c|c|c|c|c|c|c|c|}
\hline Criteria/study & $\begin{array}{l}\text { Ballard } \\
\text { et al. }{ }^{20}\end{array}$ & $\begin{array}{l}\text { Hoffmann } \\
\text { et al. }{ }^{23}\end{array}$ & $\begin{array}{c}\text { Cancela } \\
\text { et al. } .^{22}\end{array}$ & $\begin{array}{l}\text { Telenius } \\
\text { et al. }{ }^{4}{ }^{4}\end{array}$ & $\begin{array}{l}\text { Öhman } \\
\text { et al. }{ }^{21}\end{array}$ & $\begin{array}{l}\text { Lamb } \\
\text { et al. }{ }^{25}\end{array}$ & $\begin{array}{l}\text { Henskens } \\
\text { et al. } .^{19}\end{array}$ \\
\hline Random allocation & Yes & Yes & Yes & Yes & Yes & Yes & Yes \\
\hline Blinding of allocation & Yes & Yes & Yes & Yes & Yes & Yes & Yes \\
\hline Similar groups & Yes & Yes & Yes & Yes & Yes & Yes & Yes \\
\hline Blinding of participants & No & No & No & No & No & No & No \\
\hline Blinding of therapists & No & No & No & No & No & No & No \\
\hline Blinding of evaluators & Yes & Yes & No & Yes & No & Yes & Yes \\
\hline$<15 \%$ loss sample & No & Yes & No & Yes & Yes & Yes & No \\
\hline Analysis by intention to treat & Yes & Yes & Yes & Yes & No & Yes & No \\
\hline Difference between groups & Yes & Yes & Yes & Yes & Yes & Yes & Yes \\
\hline Trend measurements central and variability & Yes & Yes & Yes & Yes & Yes & Yes & Yes \\
\hline Total $(0-10)$ & 7 & 8 & 6 & 8 & 6 & 8 & 6 \\
\hline
\end{tabular}

\section{DISCUSSION}

The systematic review of the 7 randomized clinical trials provided substantial information regarding the benefits of physical exercises in controlling BPSD. Of the seven articles, four ${ }^{20,22,21,22,23,24}$ indicated improvements, while three demonstrated less ${ }^{21}$ or no benefit ${ }^{19,25}$.

Previous reviews had generalist approaches, combining studies that associated exercise with other activities, addressing different outcomes: cognition, antipsychotic drugs usage, falls, ADLs, and mortality ${ }^{9,15,16}$. However, our review avoided heterogeneity of studies and sought to include articles that presented at least one group with systematic physical exercise interventions and their relationship with BPSD. In this way, we tried to elucidate the evidence avoiding masking the results by overlapping different interventions.

Only two articles combined other interventions with exercise $^{19,20}$. Nevertheless, they presented an intervention with only exercise, not associated with other interventions, meeting the eligibility criteria of this review. The study conducted by Ballard et al. ${ }^{20}$ analyzed the effects of antipsychotic, exercise, and social interaction, and indicated a positive effect in reducing NPS; while the study carried out by Henskens et al. ${ }^{19}$ included 3 groups (exercise, ADLs training, and ADLs combined with ADLs training), not showing benefits in BPSD.

Regarding the effects of exercise, it is worth mentioning that the study conducted by Öhman et al. ${ }^{21}$ demonstrated a small reduction in BPSD and this result may be related to the fact that patients had already started the program with a low total NPI, since almost all of them were using antipsychotics for AD. Similarly, in the study by Henskens et al. ${ }^{19}$, the authors stated that no absolute conclusions could be drawn regarding the effectiveness of the exercise intervention because there was a moderate (55\%) adherence to treatment and a limited number of intensity reports.
Another study ${ }^{9,26}$ reported higher adherence rates (>75\%), and multicomponent exercise reduced depression and agitation levels. In the study by Lamb ${ }^{25}$, despite a large sample size with relatively high doses of exercise and good compliance, no significant differences were observed in cognitive or neuropsychiatric measures. The authors discuss study limitations such as 1) lack of proper allocation masking, 2) measurement bias, and 3) a high number of people who declined to participate in the trial with significant gender differences. They also hypothesize that high intensity training in healthy humans can have negative short-term effects, including slow reoxygenation of cortical areas with a transient reduction in executive function. However, the authors did not discuss how this could apply to BPSD measures and it is our impression that high intensity protocols do not fit all individuals and could lead to lower subjective well-being.

Overall, regarding the types of protocol or specific modalities of exercise, 4 of the 7 studies indicated significant improvements in BPSD. However, most reports did not specify what type of BPSD benefited more from interventions. Telenius et al. ${ }^{24}$ reported that their intervention of highintensity exercises, along with balance and resistance training, mostly reduced apathy with a tendency towards improving agitation after 12 weeks. In the study by Hoffmann et al. ${ }^{23}$ there were less severe neuropsychiatric symptoms after 16 weeks, but the intervention did not reduce depressive symptoms. In most studies, symptoms of depression responded poorly to interventions. This finding could be related to the low scores of depression in baseline samples. In their study, Telenius et al. ${ }^{24}$ observed that only $23 \%$ of participants scored above the cutoff value of eight points in the Cornell Scale for Depression in Dementia (CSDD). Only one study included in the analysis ${ }^{19}$ reported a mean baseline CSDD of 8.3 in the intervention group compared to 8.1 in controls. Moreover, we hypothesize that different strategies of social 
interaction could interfere in the depression scores, as controls often had access to usual group activities, while individuals in the intervention groups would often exercise under individual supervision.

The majority of the studies were conducted in longterm facilities. These facilities tend to house a large proportion of the elderly population with dementia, as this is one of the main causes of institutionalization of the elderly ${ }^{27}$. The included studies analyzed different stages of dementia (MCI and advanced dementia). Because of such heterogeneity in the samples, the results of the studies must be interpreted with caution, as in advanced stages, the exercise may not be viable or may not generate the same effects as in initial stages of the disease.

The studies included in our analysis did not explore in depth the mechanisms involved in BPSD reduction and this is probably multifactorial. The brain has a high plasticity and physical exercises could influence the production of neurotrophic factors leading to improved network signaling, cell growth, and cell differentiation ${ }^{28}$. One recent traumatic brain injury study showed that ten days of moderate intensity treadmill exercise reduced anxiety-like behavior, improved hippocampus-dependent spatial memory, and promoted hippocampal proliferation and newborn neuronal survival in rodents ${ }^{29}$. In structural Magnetic Resonance Imaging studies, physical activity was associated with larger brain volumes (less brain atrophy), specifically in brain regions vulnerable to dementia, comprising the hippocampus, temporal, and frontal regions ${ }^{30}$. Physical activities can modulate brain maintenance and compensation, resulting in improved resistance against degenerative pathologies ${ }^{31}$. Together with improvements in routine and social interaction and sleep and appetite regulation, we believe that there could be a reasonable neural basis for changes in BPSD following regular practice of physical exercise.

The benefits of regular physical activity in preventing dementias are already well known, as is its protective role on cognition in patients with $\mathrm{MCI}^{32}$. On the other hand, the evidence of physical exercise in reducing behavioral symptoms still needs further investigation and this systematic review reinforces the need for more intervention studies with appropriate methods, larger populations, and that investigate the effects of physical exercise as a single intervention.

We also highlight that non-pharmacological measures are currently the most effective in managing behavioral symptoms $^{33}$. Supervised physical exercise seem to be a highly costeffective strategy because of its low cost and additional benefits in terms of subjective well-being, ${ }^{34}$ protection against falls, and prevention of sarcopenia ${ }^{35,36}$.

As a limitation of this review, we point out to the small number of studies found. Besides, we are aware that the application of the PICOS strategy brings more rigor to this area of scarce data. To our knowledge, and although some studies are secondary analyzes, this is the first systematic review to include only randomized clinical trials of interventions specifically focused on physical exercise and its relationship with BPSD.

In conclusion, moderate to intense aerobic and muscle strengthening exercises may have a potential benefit in the management of BPSD, but studies reached mixed conclusions. This review demonstrated that further intervention and meta-analysis studies are needed in the area, aiming to investigate the absolute effect of physical exercise and its impact on the behavioral and psychological symptoms of elderly people with dementia, especially in the early stages of the disease.

\section{References}

1. World Health Organization. ICD-10 classification of mental and behavioural disorders. WHO [accessed on Sep 16, 2020]. Available at: https://www.who.int/substance_abuse/terminology/icd_10/en/

2. Petersen RC, Lopez O, Armstrong MJ, Getchius TSD, Ganguli M, Gloss D, et al. Practice guideline update summary: Mild cognitive impairment: Report of the Guideline Development, Dissemination, and Implementation Subcommittee of the American Academy of Neurology. Neurology. 2018 Jan;90(3):126-35. https://doi. org/10.1212/WNL.0000000000004826

3. Steinberg M, Corcoran C, Tschanz JT, Huber C, Welsh-Bohmer K, Norton MC, et al. Risk factors for neuropsychiatric symptoms in dementia: The Cache County Study. Int J Geriatr Psychiatry. 2006 Sep;21(9):824-30. https://doi.org/10.1002/gps.1567.

4. Cerejeira J, Lagarto L, Mukaetova-Ladinska EB. Behavioral and psychological symptoms of dementia. Front Neurol. 2012 May;3:73. https://doi.org/10.3389/fneur.2012.00073

5. Gerlach LB, Kales HC. Managing behavioral and psychological symptoms of dementia. Psychiatr Clin North Am. 2018 Mar;41(1):127-39. https://doi.org/10.1016/j.psc.2017.10.010
6. Health NCC for M. Dementia: supporting people with dementia and their carers in health and social care. 2011 [accessed on Sep 16, 2020]. Available at: https://researchportal.bath.ac.uk/en/publications/ dementia-supporting-people-with-dementia-and-their-carers-in-heal

7. Rabinovici GD. Late-onset Alzheimer disease. Continuum (Minneap Minn). 2019 Feb;25(1):14-33. https://doi.org/10.1212/ CON.0000000000000700

8. Ferretti C, Sarti FM, Nitrini R, Ferreira FF, Brucki SMD. An assessment of direct and indirect costs of dementia in Brazil. PLoS One. 2018 Mar;13(3):e0193209. https://doi.org/10.1371/journal.pone.0193209

9. Thuné-Boyle ICV, Iliffe S, Cerga-Pashoja A, Lowery D, Warner J. The effect of exercise on behavioral and psychological symptoms of dementia: towards a research agenda. Int Psychogeriatr. 2012 Jul;24(7):1046-57. https://doi.org/10.1017/S1041610211002365

10. Kales HC, Gitlin LN, Lyketsos CG, Detroit Expert Panel on Assessment and Management of Neuropsychiatric Symptoms of Dementia. Management of neuropsychiatric symptoms of dementia in clinical settings: recommendations from a multidisciplinary expert panel. J Am Geriatr Soc. 2014 Apr;62(4):762-9. https://doi.org/10.1111/jgs.12730 
11. Caspersen CJ, Powell KE, Christenson GM. Physical activity, exercise, and physical fitness: definitions and distinctions for health-related research. Public Health Rep. Mar-Apr 1985;100(2):126-31.

12. Deslandes AC, Moraes H, Alves H, Pompeu F a. MS, Silveira H, Mouta $\mathrm{R}$, et al. Effect of aerobic training on EEG alpha asymmetry and depressive symptoms in the elderly: a 1-year follow-up study. Braz J Med Biol Res 2010 Jun;43(6):585-92. https://doi.org/10.1590/S0100$879 \times 2010007500041$

13. Aman E, Thomas DR. Supervised exercise to reduce agitation in severely cognitively impaired persons. J Am Med Dir Assoc. 2009 May;10(4):271-6. https://doi.org/10.1016/j.jamda.2008.12.053

14. Christofoletti G, Oliani MM, Bucken-Gobbi LT, Gobbi S, Beinotti F, Stella F. Physical activity attenuates neuropsychiatric disturbances and caregiver burden in patients with dementia. Clinics (Sao Paulo). 2011;66(4):613-8. https://doi.org/10.1590/s180759322011000400015

15. Forbes D, Forbes SC, Blake CM, Thiessen EJ, Forbes S. Exercise programs for people with dementia. Cochrane Database Syst Rev. 2015 Apr;(4):CD006489. https://doi.org/10.1002/14651858. CD006489.pub4.

16. de Souto Barreto P, Demougeot L, Pillard F, Lapeyre-Mestre $M$, Rolland Y. Exercise training for managing behavioral and psychological symptoms in people with dementia: A systematic review and meta-analysis. Ageing Res Rev. 2015 Nov;24(Pt B):27485. https://doi.org/10.1016/j.arr.2015.09.001

17. Moher D, Liberati A, Tetzlaff J, Altman DG, PRISMA Group. Preferred reporting items for systematic reviews and meta-analyses: the PRISMA statement. PLoS Med. 2009 Jul;6(7):e1000097. https://doi. org/10.1371/journal.pmed.1000097

18. PEDro scale. PEDro [accessed on Oct 18, 2020]. Available at: https:// staging-pedro.neura.edu.au/english/resources/pedro-scale/

19. Henskens M, Nauta IM, van Eekeren MCA, Scherder EJA. Effects of physical activity in nursing home residents with dementia: a randomized controlled trial. Dement Geriatr Cogn Disord. 2018;46(12):60-80. https://doi.org/10.1159/000491818

20. Ballard C, Orrell M, YongZhong S, Moniz-Cook E, Stafford J, Whittaker $\mathrm{R}$, et al. Impact of antipsychotic review and nonpharmacological intervention on antipsychotic use, neuropsychiatric symptoms, and mortality in people with dementia living in nursing homes: a factorial cluster-randomized controlled trial by the Well-Being and Health for People With Dementia (WHELD) Program. Am J Psychiatry. 2016 Mar;173(3):252-62. https://doi.org/10.1176/appi.ajp.2015.15010130

21. Öhman H, Savikko NRN, Strandberg TE, Kautiainen H, Raivio MM, Laakkonen ML, et al. Effects of frequent and long-term exercise on neuropsychiatric symptoms in patients with Alzheimer's disease - Secondary analyses of a randomized, controlled trial (FINALEX). Eur Geriatr Med. 2017 Apr;8(2):153-7. https://doi. org/10.1016/j.eurger.2017.01.004

22. Cancela JM, Ayán C, Varela S, Seijo M. Effects of a long-term aerobic exercise intervention on institutionalized patients with dementia. J Sci Med Sport. 2016 Apr;19(4):293-8. https://doi.org/10.1016/j. jsams.2015.05.007

23. Hoffmann K, Sobol NA, Frederiksen KS, Beyer N, Vogel A, Vestergaard $\mathrm{K}$, et al. Moderate-to-high intensity physical exercise in patients with alzheimer's disease: a randomized controlled trial. J Alzheimers Dis. 2016;50(2):443-53. https://doi.org/10.3233/JAD-150817
24. Telenius EW, Engedal K, Bergland A. Effect of a high-intensity exercise program on physical function and mental health in nursing home residents with dementia: an assessor blinded randomized controlled trial. PLoS One. 2015 May;10(5):e0126102. https://doi. org/10.1371/journal.pone.0126102

25. Lamb SE, Sheehan B, Atherton N, Nichols V, Collins H, Mistry D, et al. Dementia And Physical Activity (DAPA) trial of moderate to high intensity exercise training for people with dementia: randomised controlled trial. BMJ. 2018 May;361. https://doi.org/10.1136/bmj. k1675

26. Resnick B, Simpson M, Bercovitz A, Galik E, Gruber-Baldini A, Zimmerman S, et al. Pilot testing of the Restorative Care Intervention: impact on residents. J Gerontol Nurs. 2006 Mar;32(3):39-47. https://doi.org/10.3928/00989134-20060301-07

27. Ooi $\mathrm{CH}$, Yoon PS, How CH, Poon NY. Managing challenging behaviours in dementia. Singapore Med J. 2018 Oct;59(10):514-8. https://doi. org/10.11622/smedj.2018125

28. de Sousa Fernandes MS, Ordônio TF, Santos GCJ, Santos LER Calazans CT, Gomes DA, et al. Effects of physical exercise on neuroplasticity and brain function: a systematic review in human and animal studies. Neural Plast. 2020 Dec;2020. https://doi. org/10.1155/2020/8856621

29. Karelina K, Schneiderman K, Shah S, Fitzgerald J, Velazquez Cruz R, Oliverio R, et al. Moderate intensity treadmill exercise increases survival of newborn hippocampal neurons and improves neurobehavioral outcomes following traumatic brain injury. $J$ Neurotrauma. 2021 Jun;38(13):1858-69. https://doi.org/10.1089/ neu.2020.7389

30. Domingos C, Pêgo JM, Santos NC. Effects of physical activity on brain function and structure in older adults: A systematic review. Behav Brain Res. 2021 Mar;402:113061. https://doi.org/10.1016/j. bbr.2020.113061

31. Cabeza R, Albert M, Belleville S, Craik FIM, Duarte A, Grady CL, et al. Maintenance, reserve and compensation: the cognitive neuroscience of healthy ageing. Nat Rev Neurosci. 2018 Nov;19(11):701-10. https:// doi.org/10.1038/s41583-018-0068-2

32. Karssemeijer EGA, Aaronson JA, Bossers WJ, Smits T, Olde Rikkert MGM, Kessels RPC. Positive effects of combined cognitive and physical exercise training on cognitive function in older adults with mild cognitive impairment or dementia: A meta-analysis. Ageing Res Rev. 2017 Nov;40:75-83. https://doi.org/10.1016/j.arr.2017.09.003

33. Oliveira AMD, Radanovic M, Mello PCHD, Buchain PC, Vizzotto ADB, Celestino DL, et al. Nonpharmacological interventions to reduce behavioral and psychological symptoms of dementia: A systematic review. Biomed Res Int. 2015;2015:218980. https://doi. org/10.1155/2015/218980

34. Moura FP, Hamdan AC. Relations between subjective well-being and Alzheimer's disease: A systematic review. Dement Neuropsychol. 2020 Apr-Jun;14(2):153-8. https://doi.org/10.1590/198057642020dn14-020008

35. Roitto H, Kautiainen H, Öhman H, Savikko N, Strandberg TE, Raivio $M$, et al. Relationship of neuropsychiatric symptoms with falls in Alzheimer's disease - does exercise modify the risk? J Am Geriatr Soc. 2018 Dec;66(12):2377-81. https://doi.org/10.1111/jgs.15614

36. Landi F, Marzetti E, Martone AM, Bernabei R, Onder G. Exercise as a remedy for sarcopenia. Curr Opin Clin Nutr Metab Care. 2014 Jan;17(1):25-31. https://doi.org/10.1097/MC0.0000000000000018 